\title{
ARBITRATION VS LITIGATION - HAS THE BUSINESS MINDSET USED THE MAN- DATORY ARBITRATION CLAUSE/AGREEMENT TO COMPROMISE THE RIGHT TO TRIAL TO RESOLVE BUSINESS DISPUTES IN THE UNITED STATES
}

Lester C. Reams, Professor, JD, DPA, MPH, Online MBA Coordinator, Faculty/Cohort Advisor ACBSP Champion, Mentor and Accreditation Coordinator, Mount Saint Mary's University Los Angeles, California (USA), ORCID: https://orcid.org/0000-0002-6883-7072

Email:Lester.reams6@gmail.com

\begin{abstract}
Purpose. The purpose of the article is to reveal whether the business mindset has used the mandatory arbitration clauses/agreements to compromise the US consumer's right to a trial to resolve business disputes in the United States.

Methodology. The results of the study were obtained by the following methods: systematic and comparative methods - to determine the essence and peculiarities of historical business behavior, business ethics and mindset; time, cost and mindset factors in arbitration vs litigation from the businesses' and consumers' perspectives; analysis and synthesis methods - to reveal the complex historic factors and interests that pre-determined the formation and application of arbitration.

Findings. In accordance with the study objectives, the author:

1) identified that business mindset was focused on making a profit and doing whatever it takes to make that profit and achieve the ambition of the business owner(s);

2) observed that companies' bend towards arbitration in the US developed as a way to avoid profit loss and avoid obstacles that would impede business for achieving it ambition due to high cost and duration of litigation;

3) revealed that there was concerted effort between business and pro-business supporters to favor the use of mandatory arbitration, which waived the right to trial;

4) discovered that actions to ban mandatory arbitration have been pre-empted by the Federal Arbitration Act;

5) unveiled that during COVID 19, while jury trials are on hold, proceedings whether litigation or arbitration are still taking place remotely;

6) concluded that the business mindset used the mandatory arbitration clause/agreement to compromise the right to trial to resolve business disputes in the United States.

Originality. The author offers original insights and interpretation of historic factors leading to the development and transformation of arbitration, as an alternative to litigation, system and procedures. The article contains original analysis of the newest events and practical outcomes of the status-quo of the US Legal System.

Practical value. In the light of a growing consumer backlash as result of the abuses occurring in the arbitration process, the article may serve as a methodological and theoretical basis for further development of American business legislation in the part of dispute resolution. The United States Elections of 2020 will be a determinant of the fate of mandatory arbitration and the right to trial.
\end{abstract}

Keywords: arbitration, litigation, business mindset, mandatory arbitration clause/agreement, dispute resolution, right to trial, US Legal System.

Received: 18.04.2019

Accepted for publication: 13.05.2019

Published: 18.06.2016 
Reams, L. C. (2020). Arbitration vs Litigation - Has the Business Mindset Used the Mandatory Arbitration Clause/Agreement to Compromise the Right to Trial to Resolve Business Disputes in the United States. Bulletin of Taras Shevchenko National University of Kyiv. Public Administration, (11), 23-35. https://doi.org/10.17721/2616-9193.2019/11-3/7

Introduction. In the past 5 years the use of mandatory arbitration clauses/agreements in business has restricted the US consumer's right to trial to resolve disputes. This article will review how this evolved and whether action has been taken to resolve this issue.

How did this come about? The author was approached by one of his business law students who needed his help with a problem. At that time, the class began discussion on contracts and had completed its discussion on arbitration. The student shared with the author that the student was having problems with Amazon and wanted to know what the actions that he should take were. The author told the student that the author would assess the problem and get back to the student as soon as possible. During the author's review it was found that if there was a dispute it had to be resolved by contacting the customer services office. If the customer service representative could not resolve the customer's problem the customer's only option was to resolve the problem through arbitration and could not take the matter to small claims court. Per a review of the cases against Amazon it was found that judges dismissed the customer's court cases and indicated that upon making the agreement the customer had agreed that all disputes must be resolved through Arbitration. The author then shared the findings with the student who decided not to take any action. In later months, the author received questions from students and colleagues regarding mandatory arbitration appearing in employment contracts. In some of these contracts, arbitration was mandatory upon signing the contract which waived the employee's ability to go to court. This led to the author's question regarding the topic of Arbitration vs Litigation, whether the business mindset has used the mandatory arbitration clauses/agreements to compromise the US consumer's right to a trial to resolve business disputes in the United States?

In order to determine whether this compromise has happened, the objective of the article is as follows:

Objective 1: The article will define the US business and the business mindset, how it has evolved to the present and identify what is the current mindset.

Objective 2: The article will review the US legal system, the right to trial and the relationship of the business mindset with the legal system.

Objective 3: The article will define arbitration, determine its original purpose, and identify how and when arbitration became mandatory and restrictive because of the business mindset.

Objective 4: The article will identify whether actions have been taken to resolve the issue.

Objective 5: The impact of COVID 19 on the litigation and arbitration process.

Objective 6: Summarize the findings and provide a conclusion

\section{Analysis of the recent achievements}

The United States' Business Mindset

A business is an organization which seeks to make a profit through individuals working toward common goals (Pride, Hughes, and Kapoor, 2015). The Business mindset is a way of thinking that enables a person to uncover and see problems as opportunities, and then turn those opportunities into a business. It is an understanding that everything around us is the result of someone having an idea and then executing it (Nastor, n.d.: 1). It is unclear who or when the use of the term "Business Mindset" began. However, it began to be heavily marketed in conjunction with workshops that trained people on becoming successful entrepreneurs. Catch phrases such as business spirit, business mentality also appeared as well. The use of this term may have been encouraged with the success of Carol Dweck's 2007 book "Mindset: The New Psychology of Success (Dweck, 2007).

Unfortunately, the definition of Business Mindset does not answer how such a mindset could compromise the customer's right to trial using mandatory arbitration since the focus is on creating a business. There would have to be more information needed in order for the mindset to lead to some type of action where the focus was on creating and maintaining a business. To determine this, the author will review the historical business behavior, business ethics theories, level of power and the perception of business in the United States. 


\section{Presentation of the main research}

\section{Historical Business Behavior}

Since the beginning of civilization, the major focus of business/merchants was to sell goods and services in exchange for some type of currency that would enable that person to make a living. During this time, from antiquity to the $1700 \mathrm{~s}$, the actions of merchants in selling goods and services in the physical marketplace varied, depending on the government structure of the cultures. Belli (2018) has stated that the ancient occupations that are still used today to provide goods and services included teaching, cab driver, famers, miners, writers, doctors, and builders. Ceramics and woodwork were also common as well (American Society of Ceramics, 2019) (Timberbits, 2014). Trade disputes were addressed in many ways depending on the culture. The most common approach was that the dispute was resolved by a local official or the king, depending on the situation.

Although business merchants would collaborate on projects that may arise in a particular culture, it was not until the creation of the East India Company in the 1600s, which was an English company formed from a group of merchants, that the influence of business with the government would begin. Banham (2019) stated the following about the East India Company. "The East India Company started as a monopolistic trading body that became involved in politics and acted as an agent of British imperialism in India from the early 18th century to the mid-19th century. In addition, the activities of the company in China in the 19th century served as a catalyst for the expansion of British influence there" (Banham, 2019). This company would be the beginning of the collaboration between government and business, which would later be incorporated into the United States.

During the early years of the United States it faced difficulty with establishing its business behavior due to the numerous wars such as the War of Independence to the Civil War. Although a few merchants were successful in the trading of slaves, tobacco, guns, alcohol, cotton and other goods, the United States was behind the more established industrial powers in Europe. In his book The Age of Betrayal (2007) Jack Brady indicated that it was not until after the civil war, during the Unites States' industrial revolution, that the influence of business would take place. This revolution was known as the Gilded Age which began in 1870 and ended in 1900. The term Gilded Age was used by historians in the 1920s, who took the term from one of Mark Twain's lesser known novels, The Gilded Age: A Tale of Today, 1873 (Brady, 2007). It was during this time that the United States' business mindset was firmly established through the Gilded Age robber barons James J. Hill, Henry Ford, Andrew Carnegie, Cornelius Vanderbilt, and John D. Rockefeller and others. Brady pointed out that although the industrialization of the United States brought wealth to a handful of people, this industrial revolution left the remaining citizens to struggle as wage laborers. The labor opportunities were limited to the factories or farms. He also (2007) added that those who accumulated this wealth used it to influence the government at all levels through unregulated campaign contributions, vote buying and the creation of laws and policies that favored their self-interest. John Naughton (2012) summed up the behavior and mindset of business when he stated: "In addition to building a modern industrial state, these gents amassed huge fortunes for themselves using a raft of dubious techniques, including fraud, stock-dilution, the bribing of corrupt politicians, the creation of secret cartels (ironically called "trusts") and the ruthless exploitation of poorly paid, non-unionized workers - which is why Matthew Josephson dubbed them "robber barons" in his book of the same title" (Naughton 2012: 5-6). Naughton added the following: "In the end, their abuses and excesses led to a legislative backlash in the form of the 1890 Sherman Anti-Trust Act, the first federal statute to limit cartels and monopolies, and to a more general public revulsion ushered in by Theodore Roosevelt's presidency in 1901" (Ibid.). Unfortunately, other events such as World War I and II, Korean War, Vietnam, 9/11, Gulf Wars I and II would be a major distraction where the business mindset was not as important except as part of the support of the economy. It was also during this period where the standard of living would improve as result of the work of government and business. Institution such as the courts system and government agencies that enforced fair labor standards were seen as the positive steps needed to maintain a fair society in the United States. Naughton (2012) concluded that: "In the twilight of their lives, some of the barons (for example Carnegie, Mellon and Frick) sought to acquire public respectability - or perhaps bargaining chips for negotiating 
with the Almighty - by endowing charitable foundations and eponymous museums, and engaging in other public-spirited enterprises" (Ibid: 6).

Unfortunately, by the $21^{\text {st }}$ century Naughton indicated that the business behavior of the Gilded Age would have a slight resurfacing with the new-tech moguls including Co-founders of Google Larry Page and Sergey Brin, Chairman and CEO of Dell Michael Dell, Co-founder of Microsoft Bill Gates, and Chairman and CEO of Facebook Mark Zuckerberg and Jeff Bezos CEO of Amazon (Naughton, 2012) Naughton pointed out the following: "What gets lost in the reality distortion field that surrounds these technology moguls is that, in the end, they are fanatically ambitious, competitive capitalists. They may look cool and have soothing bedside manners, but in the end these guys are in business not just to make money, but to establish sprawling, quasimonopolistic commercial empires. And they will do whatever it takes to achieve those ambitions" (Ibid.: 5).

Also added to the business behavior is the appearance of psychopathic behavior. Forbes Magazine's Senior Contributor Jack McCullough asserted in his 2019 article "The Psychopathic CEO" that the "Me too" movement has raised awareness of psychopaths in corporate environments. In the article Karen Landay, a Ph.D. candidate in business management at University of Alabama, described the psychopath as the following: "They are typically very charming on the surface, they are bold and not afraid..."They don't care that they are hurting you. They will do what they have to do" (McCullough, 2019: 5). McCullough added that there is much contention over the presence of psychopathy in corporate America. The most recent estimate is between $8 \%$ and $12 \%$. Currently, it is unknown whether psychopathy is present in businesses outside of corporate America. However, McCullough pointed out that Landay found no conclusive evidence indicating that a large percentage of CEOs are psychopaths (Ibid).

What can be concluded is that business behavior is concerned with providing goods, services and making a profit. How it is done depends on the ambition of the business owner(s)/CEO regardless of whether they exhibit some form of psychopathic behavior or not. But a running theme that has been identified in business ethics theories is the act of doing whatever it takes to achieve this profit and ambition.

\section{Business Ethics Theories}

Business Ethics theories have and continue to have a major impact on business behavior. The focus of business ethics is the content, development, management, and effectiveness of the codes of conduct designed to guide the actions of people engaged in business activity (Stanford Encyclopedia, 2016). Elkins (2019) pointed out that Business ethics are often discussed today, in light of corporate scandals (Elkins, 2019). Often, this discussion focuses on professional conduct or illegal practices. The issue of ethics in business is not a new subject. As a matter of fact, academics, philosophers, practitioners, and government regulators have struggled over its application for decades. Unfortunately, there is the belief that unethical, immoral, and/or illegal behavior has become widespread in the business world in light of the movement towards more transparency. The numerous scandals in the late 1990s and 2000s seemed to add credence to this belief. In John Conley's 2019, article of ethics he noted the following: "Corporate executives of WorldCom, a giant in the telecommunications field, admitted fraud and misrepresentation in financial statements. WorldCom's former CEO went on trial for alleged crimes related to this accounting ethics scandal. A similar scandal engulfed Enron in the late 1990s and its former CEO, Ken Lay, who also when on trial. Other notable ethical lapses were publicized involving ImClone, a biotechnological firm; Arthur Andersen, one of the largest and oldest public accounting firms; and Health South, a large healthcare firm located in the southeast United States. These companies eventually suffered public humiliation, huge financial losses, and in some cases, bankruptcy, or dissolution (Conley, 2019). In Andrew Stark's (1993) article What's the Matter with Business Ethics? he stated that these scandals were responsible for the increased interest in Business Ethics where the focus would be to assess what was occurring in business leadership behavior and mindset (Stark, 1993)

During this period business ethicist had the opportunity to identify what was the common philosophy that was prevalent in business. From a review of numerous studies, the University of Texas at Austin McCombs School of Business concluded the following: "Utilitarianism holds that the most ethical choice is the one that will produce the greatest good for the greatest number. It is the only moral framework that can be used to justify military force or war. It is also the most common approach to moral reasoning used in business because of the way in which it accounts for costs and benefits" (McCombs School of Business, 2020). 
Utilitarian tends to favor the notion of the "end justifies the means" which is often connected to the Robber Baron's action of doing whatever it takes to achieve ones ambitions.

Unfortunately, Stark (1993) concluded while the major American corporations were trying to build ethics into their organizations, the problem was that the discipline of business ethics had not provided concrete help to managers in dealing with two ethical challenges: (1) identifying ethical courses of action in difficult gray-area situations (the kind that Harvard Business School Lecturer Joseph L. Badaracco, Jr. has described as "not issues of right versus wrong," but "conflicts of right versus right"); and, (2), navigating those situations where the right course is clear, but real-world competitive and institutional pressures lead even well-intentioned managers astray. As an example, it would be unfair to ask managers to take an altruistic stance where the manager sacrificed profits that are expected by the shareholder to do the right thing. To leaders, manager and other business professionals, business ethicists were taking an absolutist approach of all or nothing without understanding the consequences. From his assessment, Stark (1993) indicated that the options that business ethicist presented were too theoretical and/or too impractical. Due to repeated scandals, Stark concluded that business ethicist had to develop a new set of business ethics approaches. The scholar later identified a glimmer of hope where he shares: "In the fittingly final essay of Business Ethics, Joanne B. Ciulla provides a breath of fresh air when she writes, "the really creative part of business ethics is discovering ways to do what is morally right and socially responsible without ruining your career and company"(Stark, 1993 p 14). In 2019 Nicholas Epley and Amit Kuma's article How to Design an Ethical Organization placed the responsibility on the business owner to take an active role in creating an ethical business. Epley and Kuma's' approach moved away from the prior ideas that: (1) there was one ethical standard and (2) the use of incentives given to business personnel so that they behave in an ethical manner was immoral. Epley and Kuma added that "Creating an ethical culture required thinking about ethics not simply as a belief problem but also as a design problem. Epley and Kuma asserted they had identified four critical features which needed to be addressed when designing an ethical culture. These four critical features included explicit values, thoughts during judgment, incentives, and cultural norms." Unfortunately, the new approaches to Business Ethic kept in place the: (1) Utilitarianism view of the greatest good, (2) the ends justify the means and (3) do whatever it takes to achieve ones ambitions, while discovering ways to do what is morally right and socially responsible.

\section{Level of Power}

As stated by Banham (2019) the East India Company became involved in politics and acted as an agent of British imperialism in India from the early $18^{\text {th }}$ century to the mid- $19^{\text {th }}$ century. The same actions took place in the United States during the Gilded Age where the Robber Barons got involved in politics so that future laws would impede their ability to make a profit. Since the Gilded Age, the wealthy have managed to stay in power to protect their own self-interest either through money, lobbyist or becoming politicians. While this has been beneficial for the wealthy, small and medium size businesses have not had the opportunity to participate unless they have become members of organizations that represent their interest, such as local Chamber of Commerce or business associations. Unfortunately, large corporations are also members of these organizations as well which tends to drown out the smaller businesses voices. One aspect that is encouraged by large corporations and business consultants is that small and medium size business owners incorporate tools and approaches that have been used by corporations so that small or medium size businesses can protect their selfinterest and maximizing their profits as well.

\section{Perception of Business}

Elkins' (2019) article Ethical Theories in Business has stated that "These days, many consumers select products based on ethical considerations. Buyers trust that the companies with which they conduct business are responsible and moral. Unfortunately, David Michel's (2019) article The Trust Crisis in Business concluded that there is a trust gap between business and the customer because of cybersecurity exploits leading to misuse of corporate or personal data; scandals and indictments of prominent businesspeople; and the intentional release of misleading or inaccurate information, and its subsequent spread via social media networks.

The final conclusion regarding the United States' Business Mindset is that in light of events such as wars, the Depression and great recession and numerous scandals the mindset has made adjustments to fit the 
generations, but by and large has not changed due to the trust gaps that business currently faces because of its behavior.

Legal System vs Unites States Business Mindset

This section will cover the legal system, the right to a trial by jury, the Rule of Law and the role of the Court and its connection to business, litigation and cost, and how the business mindset views the court system.

\section{Legal System}

The United States' Legal system was develop by the framers of the Constitution under Article III which stated "The judicial power of the United States, shall be vested in one Supreme Court, and in such inferior courts as the Congress may from time to time ordain and establish. The judges, both of the supreme and inferior courts, shall hold their offices during good behavior, and shall, at stated times, receive for their services, a compensation, which shall not be diminished during their continuance in office." (U.S. Const. art. III, $\mathbb{1}$ 1.)

On September 24, 1789, President George Washington signed into law The Judiciary Act of 1789. This act established the structure and jurisdiction of the federal court system and created the position of attorney general (The Judiciary Act of 1789). The current structure of the federal court consists of 94 district-level trial courts, 13-courts of appeals and the Supreme Court. Each state has established a similar structure of trial courts, courts of appeals and a supreme court (Understanding the Federal Courts, 2020).

\section{Right to a Trial by Jury, Rule of Law and the Role of the Court and its connection to Business}

Right to a Trial: The Right to a trial by jury is provided through the Seventh Amendment of the Unites States Constitution under the federal court system. This Amendment did not cover the states unless the states were addressing federal related issues. Later, the Right to a Trial by Jury came to states through the Sixth Amendment (Right to a public trial) and the Fourteenth Amendment (Equal Protection of the Law). These amendments included both criminal and civil cases. The notion of a Right to trial or even the entire United States Legal system could not operate if the framers and colonist had not made the decision that the new country called the United States would follow the Rule of Law. The creation of the United States Constitution set the foundation for the Rule of Law.

Rule of Law: The American Bar Association (ABA) defines the rule of law as a set of principles, or ideals, for ensuring an orderly and just society. Further, the ABA states that no country can maintain a rule of law society if its people does not respect the laws. Everyone must make a commitment to respect laws, legal authorities, legal signage and signals, and courts. The ABA adds that the benefits is that upholding the rule of law ensures that no one is above the law, everyone is treated equally under the law, everyone is held accountable to the same laws, there are clear and fair processes for enforcing laws, there is an independent judiciary, and human rights are guaranteed for all (American Bar Association, 2019).

Role of The Courts: The role of the courts is to act as the independent judiciary. The ABA states the following: "An independent judiciary is necessary to ensure the rule of law is respected. Judicial independence means that judges are not subject to pressure and influence and are free to make impartial decisions based solely on fact and law. An independent judge can assure that your case will be decided according to the law and the facts and not a shifting political climate (American Bar Association, 2019).

Courts Relations to Business: In its review of courts relations to the business the ABA concluded the following: "Retail and trade would grind to a halt if businesses could not rely on the courts for enforcement of their rights." The ABA added that "businesses rely heavily on the courts to protect their contractual and property rights. If businesses cannot count on being able to resort to the courts when they need to, there can be certainty that legal and contractual obligations will be carried out (American Bar Association, 2019).

\section{Litigation Process and Cost}

Litigation is defined as the act, process, or practice of settling a dispute in a court of law ("Litigation," n.d.) A more detailed description of litigation is that it is an action between two opposing parties with the aim 
of either enforcing or defending a legal right. The parties have the option of settling the matter through a settlement agreement or going to court where a judge or jury determines the final resolution. The litigation process consists of Pleadings, Discovery, Summary Judgment, Final Preparation, Trial, Jury Instructions, Deliberations and Verdict, and Motion/Appeal/Settlement. Although, there is the commitment to the rule of law the actual process from start to finish can take 18 months or more if a Civil suit and shorter for a Criminal suit since the Constitution requires a right to a speedy trial. The reason that the process is so long is because of availability of courts and that there are procedures built into the process where both parties have months to complete that process. Unfortunately, to the public the litigation process appears to be slow causing all parties involved to become frustrated with the system.

Over the years, the cost of the litigation process has increased to the point where it has become extremely expensive to pay for the process. John O Newman (1985) stated the following: "For decades critics of the litigation system have bemoaned the delays and costs of courtroom encounters while working mightily to refine the system in ways that make it even slower and more expensive." Bruce Cannon Gibney, a litigator turned venture capitalist, added that the "American Legal system has decayed over the last 70 years where laws have become needlessly complex as result of politics and the influence of money. Gibney observed that the laws became bloated out of control where there are 50,000 rules for everything. The area that has contributed to the cost for business has been tort litigation. Bonner (2019) indicates that the other problem is that business has complained that lawyers are clogging the legal system with too many frivolous lawsuits. As a result, President George W. Bush supported legislation aimed at tort reform. As a counterpoint, Bonner states that the critics of tort reform argue that the real purpose is to shield business from having to pay consumers, patients and clients for damages as a result of fraud, negligent or other tort claims caused by business; Bonner adds that such reforms limit people's ability to obtain justice for injuries they have suffered. Finally, Bonner pointed out that since many victims cannot afford a lawyer their cases are handled on a contingency fee basis. Unfortunately, this has resulted in matters being unresolved due to a lack of money and parties looking to alternatives that are cheaper that can resolve the dispute faster. Gibney (2019) makes the final assertion that as a result of litigation process being incredibly expensive, this has led to two outcomes: (1) business was driven to pursue arbitration and (2) since courts were bog down due to the increase of regulation, which were very complex, such changes favor large companies because they were the only ones to be able to afford having in place compliance teams, legal department and pay law firm charges.

\section{Business Mindset View}

Based on the above, the business mindset, as a result of the United States commitment to the Rule of Law, views the courts as necessary in protecting business self-interests. This mindset tolerates those circumstances where the court may or may not rule in businesses favor. Yet, this mindset would consider alternatives that are cheaper and faster which would protect and preserve the self-interest of the business.

Arbitration origins, its restriction, and the Business Mindset Connection

This section will define arbitration, determine its original purpose, and identify how and when arbitration changed and became restrictive because of the business mindset connection.

Arbitration is defined by the American Bar Association (2013) as a private process where disputing parties agree that one or several individuals called a neutral arbitrator can make a decision about the dispute after receiving evidence and hearing arguments. The ABA adds that the arbitration process may be either binding or non-binding. When arbitration is binding, the decision is final, can be enforced by a court, and can only be appealed on very narrow grounds. When arbitration is non-binding, the arbitrator's award is advisory and can be final only if accepted by the parties (ABA, 2020). Should the validity of the arbitration agreement/clause be questioned, the validity of an arbitration agreement/ clause can be decided by a court rather than an arbitrator.

\section{Original Purpose}

Arbitration has been used as a dispute-resolution tool for thousands of years. Since its inception, arbitration has existed in an uneasy tension with courts of law. The courts and public were very slow to embrace and some were outwardly hostile. The attitude toward arbitration existed into the $17^{\text {th }}$ Century England where under the British common law, per the Dictum of Vynior's case of Lord Coke, agreements to arbitrate were not enforceable (Heuston,1926). It was not until the Industrial revolution of the Gilded Age and into the 
$20^{\text {th }}$ Century that large corporations began to oppose this policy against the use of arbitration. Because of this opposition, the main argument given by these corporations is that the application of the British common law had destroyed relations for American Business since the laws used were not applicable to the norms and customs used in business.

In 1920, after much opposition, the state of New York created the New York Arbitration Act. Years later, the United States Arbitration Act of 1925 was established. The act would later be known in the present as the Federal Arbitration Act. Following enactment of the 1925 act, the American Arbitration Association (AAA) was established in 1926, with the mission of helping to implement arbitration as an out-of-court solution to resolving disputes (Stone and Colvin, 2015). The argument asserted by the AAA (n.d.) for supporting the use of arbitration was that arbitration was faster and more cost effective than litigation. The expansion of arbitration, as a result of the AAA efforts, has allowed it to develop new areas such as commercial arbitration, construction arbitration, employment arbitration, international arbitration, labor arbitration, government arbitration and consumer arbitration.

\section{Changes in Arbitration towards Restrictions of the Right to a Trial}

Towards the end of the $20^{\text {th }}$ Century arbitration had become the most common and popular alternative dispute resolution tool for business. In Martha Neil's 2005 article "Litigation over Arbitration she stated: "Arbitration is extremely popular among U.S. companies that view it as a manageable and efficient vehicle for resolving disputes with other commercial entities and consumers while avoiding time consuming, costly litigation" (Neil, 2005 p 1). It was not until the 1995 Supreme Court Case Allied Bruce Terminix Companies v. Dobson where the U.S. Supreme Court ruled that mandatory arbitration agreements could be enforced under federal law. Neil concluded that "since then, mandatory arbitration clauses have become common in a myriad of consumer contracts, employment agreements and benefit plans (Neil, 2005: 2), Neil's article cites Cliff Palefsky who practices consumer and civil rights law in San Francisco, who argued that the decision "preempted all the consumer protection legislation that existed in the states. Because there's no federal consumer protection legislation, they've basically eliminated it rather than replaced it. So, there's a huge void" (Ibid.: 2). Rather than address the issue, Sternlight (2003) has indicated that the Supreme Court has issued numerous decisions stating that arbitration should be looked upon with favor and that, with few exceptions, arbitration clauses should be enforced." Neil and consumer advocates concluded that additional legislation needs to be created to fill the huge void so that consumers are provided with proper consumer protection (Neil, 2005).

How arbitration agreements became restricted occurred when the process changed from optional to mandatory arbitration agreements. Under a mandatory arbitration agreement, the final decision of the arbitrator is binding. The right to a trial is waived. Kramer and Kushner (2019) indicated that one of the benefits of arbitration is that the decision is final. The problem that occurs is that there is no mechanism to reverse egregious errors of fact or law by the arbitrator or a wrong decision. Under the court system, such a decision could be reversed by one or more levels of the appellate courts. Neil (2005) cites Richard Chernick of Los Angeles, the immediate past chair of the ABA Section of Dispute Resolution, who pointed out other restrictions when he stated: "...business prefers arbitration because business likes the ability to limit discovery, set their own rules for presenting evidence, schedule proceedings at their own convenience and select the third party who will decide their cases (Neil, 2005: 1) Finally, Sternlight states that one of the most significant aspects of mandatory arbitration is that it denies claimants access to court or to a jury trial (Sternlight, 2003).

Business Mindset View

Based on the findings, the business mindset comes back to the focus of making a profit and doing whatever it takes to achieve this ambition. The "whatever it takes" aspects of the mindset would mean a preference for using arbitration since there is the opportunity to control hearings, influence the final decision, and eliminate the right to a trial.

Consumer Reaction and Actions Taken

In light of the United States Supreme Court, some politicians and businesses support of mandatory arbitration that waives the right to a trial, the consumers' reaction has been negative and has made the issue of mandatory arbitration controversial. Neil (2005) stated that "The controversy over mandatory arbitration clauses in consumer agreements is becoming so intense; say some in the field, that it's even putting the overall 
credibility of arbitration at risk." Since the Supreme Court decision in 1995, Neil interviewed David A. Hoffman, Chairs of the ABA's Dispute Resolution Section in Boston, who shared the following: "Arbitration is beginning to look more and more like litigation," he says. "There's more discovery. There's more motion practice. There are concepts such as summary judgment that until recent years were foreign to the world of arbitration" (Ibid.: 3). Currently, the distinction between arbitration and litigation has become so blurred that the cost for litigation and arbitration are similar.

Currently, consumers view mandatory arbitration as an expensive process that places consumers and employers at a disadvantage where there is a limited ability to pursue their cases. There appears to be a growing resistance as a result of the negative reaction to arbitration. The reaction has led consumers to take actions against mandatory arbitration. Two examples of actions taken are as follows:

1. The $5^{\text {th }}$ U.S. Circuit Court of Appeals, based in New Orleans, applied the unconscionability standard to invalidate a mandatory arbitration clause that required cellular phone customers-but not the company providing the service to arbitrate all disputes (Iberia Credit Bureau v. Cingular 2004).

2. The $9^{\text {th }}$ U.S. Circuit Court of Appeals, based in San Francisco, ruled that individuals challenging mandatory arbitration provisions in their telephone service agreements could not be prevented from arbitrating on a class action basis because the ban was "manifestly one sided" (Darcy Ting v. AT\&T, 2003).

Unfortunately, future cases have been struck down by the US Supreme Court because of the Court's enforcement of the Federal Arbitration Act (FAA). This enforcement has led states in the past and present to create legislation to address mandatory arbitration. The most recent examples are as follows:

In October 2019 Nagele-Piazza wrote an article titled: "New California Law Bans Mandatory Arbitration for Most Workplace Claims." where she stated: "Effective Jan. 1, 2020, California employers can no longer require workers to arbitrate state-law discrimination and labor code claims, under a bill that Gov. Gavin Newsom recently signed. But employment attorneys expect the new mandate to be challenged under a federal law that favors arbitration" (Nagele-Piazza, 2019: 1). Unfortunately, prior to the law taking effect, a district judge placed a preliminary injunction which will remain in effect until the case is resolved. Until the law is resolved employers and business will continue to include mandatory arbitration agreements in contracts. In the past, other states have made attempts to ban mandatory arbitration. For example, the state of Kentucky court tried to invalidate arbitration agreements based on the state constitution's declaration of the right of court access and the "sacred" and "inviolate" nature of trial by jury. The U.S. Supreme Court overruled the state court's decision, reinforcing its longstanding precedent of enforcing arbitration agreements under the FAA.

Since the federal courts and United States Supreme Court have been preempting state laws banning mandatory arbitration, consumers and employees have contacted their representatives in congress to address the matter. This resulted in the creation of the Forced Arbitration Injustice Repeal Act of 2019, also known as The FAIR ACT. This act prohibits pre-dispute, forced arbitration agreements from being valid or enforceable if it requires forced arbitration of an employment, consumer, or civil rights claim against a corporation. The FAIR Act passed the House of Representatives on September 20, 2019. However, it is still pending a review and vote of the Senate. (GovTrack.us, 2020).

Although action has been taken, it appears that the best way to resolve the issue is through federal legislation. Unfortunately, it will be challenging since the Senate and President are pro-business. It may take the election of new government officials that are pro-consumer to resolve the problems. Where there is a glimmer of hope is that the abuses of the gilded age that led to the creation of 1890 Sherman Anti-Trust Act are the same abuses that have created the Fair Act.

Impact of COVID 19. The impact of COVID 19 on the litigation and arbitration process has resulted in a postponement of cases to determine how to conduct various hearings while adhering to Center for Disease Control Guidelines. Currently, federal courts and courts in most states have now suspended or cancelled jury trials. As an alternative when possible some case which would include arbitration cases are being held remotely. The impact of COVID 19 will not impact the issues discussed in this article. It is hoped by the author that this period will allow all parties to reflect on the current arbitration process and its impact on the right to trial (Knowles and Kent, 2020). 


\section{Summary, Final Conclusions and Comment}

At the beginning of this article the author asked a simple question, has the business mindset used the mandatory arbitration clause/agreement to compromise the right to trial to resolve business disputes in the United States? In researching this topic each objective provided a clue to the answer. Objective 1 defined what was meant by the business mindset and identified that the focus was on making a profit and doing whatever it takes to make that profit and achieve the ambition of the business owner(s). Objective 2 focused on the United States Legal System and concluded that litigation became so expensive over the last 70 years that it drove companies towards arbitration as a way to avoid profit loss and avoid obstacles that would impede business for achieving it ambition. Objective 3 centered on arbitration, origin and the changes that occurred and has revealed that there was concerted effort between business and pro-business supporters which included America Arbitration Association, politicians and the United States Supreme Court to favor the use of mandatory arbitration, which waived the right to trial. Objective 4 discussed actions that have been taken to ban mandatory arbitration only to reveal that these actions have been pre-empted by the Federal Arbitration Act. Objective 5 shared the impact of COVID 19 on the court system and litigation and arbitration process and concluded that while jury trials are on hold, proceedings whether litigation or arbitration are still taking place remotely. Objective 6 would provide the final conclusion based on the initial question, has the business mindset used the mandatory arbitration clause/agreement to compromise the right to trial to resolve business disputes in the United States? The answer is yes for now. However, as a caveat there are signs of a growing consumer backlash as result of the abuses occurring in the arbitration process, similar to what led to the creation of the 1890 Sherman Anti-Trust Act, in the form of the FAIR Act. The United States Elections of 2020 will be a determinant of the fate of mandatory arbitration and the right to trial.

\section{References}

Allied-Bruce Terminix Cos. v. Dobson, 513 U.S. 265 (1995). Retrieved from https://www.lexisnexis.com/community/casebrief/p/casebrief-allied-bruce-terminix-cos-v-dobson

American Arbitration Association (n.d.) What We Do, Arbitration. Retrieved from https://adr.org/Arbitration

American Bar Association (2013) Alternative Dispute Resolution: Arbitration. Retrieved from https://www.americanbar.org/groups/dispute_resolution/resources/DisputeResolutionProcesses/arbitratio $\mathrm{n} /$

American Bar Association (2019) Rule of Law and the Courts Retrieved from https://www.americanbar.org/groups/public_education/resources/rule-of-law/rule-of-law-and-the-courts/

American Bar Association (2019) Rule of Law in American Life: A Long and Intentional Tradition. Retrieved from https://www.americanbar.org/groups/public_education/resources/rule-of-law/rule-of-law-inamerican-life--a-long-and-intentional-tradition/

Banham, H. (2019) Business and Industry. Retrieved from www.intriguing-history.com

Brady, J. (2007) Age of Betrayal: The Triumph of Money in America, 1865-1900, Penguin Random House New York City, 1-707.

Belli, G. (2020) Ancient Jobs that Still Exist Career News, Payscale.com. Retrieve from https://www.payscale.com/career-news/2018/05/7-ancient-jobs-that-still-exist-today

Bureau, V. Cingular Wireless, 379 F.3d 159 (2004). 
Bonner, M. (2019) What Does Tort Reform Mean? The balance of Small business Retrieved from https://www.thebalancesmb.com/marianne-bonner-462097

Dweck, C. (2007) Mindset: The New Psychology of Success. Random House publishing, New York City.

Darcy Ting V. AT\&T, 319 F.3d 1126 (2003).

Elkins, H (2019) Ethical Theories in Business, Houston Chronicle. Retrieved from https://smallbusiness.chron.com/ethical-theories-business-74122.html

Epley, N and Kuma, A (2019) How to Design an Ethical Organization Harvard Business Review. p 1-9 Retrieve from https://hbr.org/2019/05/how-to-design-an-ethical-organization

Gibney, B. C. (2019) The Nonsense Factory: The Making and Breaking of the American Legal System Hachette Books, New York.

GovTrack.us. (2020). H.R. 1423 - 116th Congress: Forced Arbitration Injustice Repeal Act. Retrieved from https://www.govtrack.us/congress/bills/116/hr1423John Conley (2020) Ethics Reference for Business https://www.referenceforbusiness.com/management/Em-Exp/Ethics.html

Heuston, A.N. (1926) The Settlement of Disputes by Arbitration Washington Law Review, Vol 1 No 4, p 243268. (Dictum Lord Coke - Vynor's Case, 4 ENG. REP. 302 (1609) Retrieved from https://digitalcommons.law.uw.edu/cgi/viewcontent.cgi?article=1022\&context=wlr

Kramer, K. B. and Kushner, A. (2019) "An Unhappy Bargain: The Downsides of Arbitration" ABA Connection. Retrieved from https://www.americanbar.org/groups/litigation/publications/litigation_journal/201920/fall/an-unhappy-bargain-downsides-arbitration/

Knowles, B. and Kenton, M. (2020) COVID-19 Global: Arbitration and court impacts, Clyde and Co. Retrieved from https://www.clydeco.com/insight/article/covid-19-impact-on-courts-and-arbitration

Litigation. (n.d.). In Merriam-Webster.com dictionary. Retrieved from https://www.merriamwebster.com/dictionary/documentation

McCombs School of Business (2020) Ethics Unwrapped University of Texas at Austin. Retrieved from https://ethicsunwrapped.utexas.edu/glossary/utilitarianism

McCullough, J. (2019) The Psychopathic CEO Forbes Magazine. Retrieve from https://www.forbes.com/sites/jackmccullough/2019/12/09/the-psychopathic-ceo/\#2b18d098791e

Michel, D. (2019) The Trust Crisis In Business. Forbes Magazine. Retrieved from https://www.forbes.com/sites/davidmichels/2019/06/17/the-trust-crisis-in-business/\#2803a41044a6

Nagele-Piazza (2019) New California Law Bans Mandatory Arbitration for Most Workplace Claims SHRMSCP. Retrieved from https://www.shrm.org/resourcesandtools/legal-and-compliance/state-and-localupdates/pages/new-california-law-bans-mandatory-arbitration.aspx

Naughton, J. (2012) New-tech moguls: the modern robber barons? The Guardian, p 5-6. Retrieved from https://www.theguardian.com/technology/2012/jul/01/new-tech-moguls-robber-barons

Neil, M. (2005) Litigation Over Arbitration ABA Journal. p 1-9 Retrieved from https://www.abajournal.com/magazine/article/litigation_over_arbitration 
Nastor, J. (n.d.) Business Hacks: 21 Simple Mindset Hacks for Entrepreneurs. p. 1 Retrieved from https://hacktheentrepreneur.com/mindset-hacks-entrepreneurs/

Newman, J.O. (1985) Rethinking Fairness: Perspective on the Litigation Process. Yale Law Review, Vol. 94, 1643-1659.

Pride, W. M., Hughes, R. J. Hughes, Kapoor J. R. (2015) Foundations of Business Cengage. Boston, MA

Stanford Encyclopedia of Philosophy (2016) Definition Business Ethics. Retrieved from https://plato.stanford.edu/entries/ethics-business/

Stark, A. (1993) What's the Matter with Business Ethics? Harvard Business Review May-June 1993 Issue. Retrieved from https://hbr.org/1993/05/whats-the-matter-with-business-ethics

Sternlight, J. R. (2003) The Rise and Spread of Mandatory Arbitration as a Substitute for the Jury Trial University of San Francisco Law Review. Vol 58, 17-38.

Stone, K. V. W. and Colvin, A. J. S. (2015) The Arbitration Epidemic Economic Policy Institute (EPI) Briefing Paper \# 414. Retrieved from https://www.epi.org/publication/the-arbitration-epidemic/

The American Ceramics Society. Retrieved from https://ceramics.org/about/what-are-engineeredceramics-and-glass/brief-history-of-ceramics-and-glass

The Judiciary Act of 1789. National Archives Foundation: Washington, DC, n.d.. Retrieved from https://www.archivesfoundation.org/documents/judiciary-act-1789/

Timberbits (2014) History of Woodworking. Retrieved from http://www.timberbits.com/about_us 2014

Wolaver, E, S. (1934) The Historical Background of Commercial Arbitration, University of Pennsylvania Law Review. Vol 83, 132-146 Retrieved from https://scholarship.law.upenn.edu/penn_law_review/vol83/iss2/2/

Understanding The Federal Courts (n.d.) Administrative Office of the U.S. Courts Retrieved from https://www.uscourts.gov/sites/default/files/understanding-federal-courts.pdf

U.S. Const. art. III, $\mathbb{\$} 1$.

\section{АРБІТРАЖ ЧИ СУДОВИЙ РОЗГЛЯД? АБО: ЧИ СКОРИСТАВСЯ ПІДПРИЄМНИЦЬКИЙ МЕНТАЛІТЕТ У США ПОЛОЖЕННЯМ / УГОДОЮ ПРО ОБОВ'ЯЗКОВИЙ АРБІТРАЖ, ЩОБ ОБМЕЖИТИ ПРАВА НА РОЗВ'ЯЗАННЯ КОМЕРЦІЙНИХ СПОРІВ В СУДІ}

Лестер С. Римс, профессор, доктор юридичних наук, доктор державного управління, магістр охорони здоров'я, координатор онлайн-МВА програм, Представник Ради з акредитачії бізнес-шкіл і програм, ментор і координатор з акредитачії, Університет Маунт-Сент-Меріс Лос-Анджелес, Каліфорнія (CIIA), ORCID: https://orcid.org/0000-0002-6883-7072,

Email:Lester.reams6@gmail.com

Отримано: 19.04 .2019

Ухвалено до друку: 13.05 .2019

Опубліковано: 18.06 .2019 
Рімс Л. С. (2020). Арбітраж чи судовий розгляд? або: чи скористався підприєм-ницький менталітет у сша положенням / угодою про обов'яз-ковий арбітраж, щоб обмежити права на розв'язання комерчійних спорів в суді. Вісник Київського начіонального університету імені Тараса Шевченка. Державне управління, (11), 23-35. https://doi.org/10.17721/2616-9193.2019/11-3/7

\section{Анотація}

Мета. Мета статті - виявити, чи скористався підприємницький менталітет в США положенням / угодою про обов'язковий арбітраж, щоб обмежити права споживачів на розв'язання комериійних спорів в судi

Методика. Результати дослідження були отримані такими методами: системним $і$ компаративний методами - для визначення сутності та особливостей історичного становлення підприємницької поведінки, ділової етики та менталітету, ролі факторів часу, витрат і менталітету в наданні переваги арбітражу перед судовим розглядом з позицій бізнесу і споживача; методами аналізу і синтезу для виявлення комплексних історичних факторів та інтересів, які зумовили становлення та функціонування системи арбітражу.

Результати. Відповідно до иілей дослідження автор:

1) визначив, що підприємницький менталітет спрямований на отримання прибутку і передбачає використання будь-яких засобів для отримання такого прибутку і досягнення иілей / амбічій власника (ів) бізнесу

2) виявив, що сприятливе ставлення до арбітражу з боку бізнес-структур США сформувалося як спосіб уникнення втрат прибутку і усунення перешкод в досягненні иілей бізнесу, внаслідок високої вартості і тривалості судових розглядів.

3) з'ясував, що підприємщі і прихильники бізнесу докладали узгоджені зусилля на користь обов'язкового арбітражу, який передбачав відмову від права на судовий розгляд aрбітраж

4) виявив, що дії по забороні обов'язкового арбітражу були скасовані Федеральним законом про

5) встановив, що в період епідемії COVID 19, в той час як засідання судів присяжних припинені, судові або арбітражні розгляди, як і раніше, ведуться дистаниійно

6) прийшов до висновку, що підприємничький менталітет в США скористався положенням / угодою про обов'язковий арбітраж, щоб обмежити права споживачів на розв'язання комериійних спорів в cydi.

Наукова новизна. Запропоновано авторське бачення та інтерпретачія історичних чинників, що привели до формування і трансформаиї системи і проиедур арбітражу як альтернативи судового розгляду. Стаття містить оригінальний аналіз новітніх подій і практичних наслідків існуючого статусу правової системи США.

Практична значимість. На тлі зростаючої негативної реакиї споживачів в результаті зловживань, що відбуваються в процесі арбітражу, стаття може слугувати методологічною і теоретичною основою для подальшого розвитку американського законодавства про підприємницьку діяльність в частині вирішення спорів. Вибори США 2020 року стануть визначальним фактором подальшої долі обов'язкового арбітражу і права на суд.

Ключові слова: арбітраж, судовий розгляд, підриємницький менталітет, положення / угода про обов'язковий арбітраж, розв'язання спорів, право на судовий розгляд, правова система США. 